\title{
Wage cyclicality: Evidence from Spain using social security data
}

\author{
Jorge De la Roca
}

Received: 31 May 2013 / Accepted: 11 June 2014 / Published online: 8 July 2014

(C) The Author(s) 2014. This article is published with open access at SpringerLink.com

\begin{abstract}
Using longitudinal social security data, this study finds evidence of weak real wage cyclicality in Spain throughout 1988-2011. The baseline estimate of a $0.4 \%$ increase in wages in response to a one percentage point decline in the unemployment rate lies in the lower bound of available estimates for developed countries. Wage cyclicality in a rigid labour market like Spain is mainly driven by workers under temporary contracts and newly-hired workers. I calculate the cyclicality of the net present value of wages in new matches - the relevant piece of information for firms posting vacancies, but a rarely available measure - and find that it is well approximated by the cyclicality of wages for newly-hired workers.
\end{abstract}

Keywords Wage cyclicality - Labour market duality - Social security data . Censoring

JEL Classification $\quad \mathrm{c} 24 \cdot \mathrm{e} 32 \cdot \mathrm{j} 31$

\footnotetext{
I thank Samuel Bentolila, Stéphane Bonhomme, Claudio Michelacci, Diego Puga, one anonymous referee and seminar participants at CEMFI for helpful comments. This work contains anonymized statistical data from MCVL CDF 2005-2011 which are used with the permission of Spain's Dirección General de Ordenación de la Seguridad Social.
}

J. De la Roca $(\bowtie)$

Furman Center for Real Estate and Urban Policy, New York University,

139 MacDougal Street, 2nd Floor, New York 10012, NY, USA

e-mail: jorge.delaroca@nyu.edu

URL: http://jorgedelaroca.name 


\section{Introduction}

Recent evidence on real wage cyclicality using worker-level data shows wages are much more cyclical than previously thought. Following the lead of Bils (1985), many studies have found that since the early 1970s individual wages respond to changes in the unemployment rate [see Pissarides (2009) for a summary of the evidence]. However, most of this evidence is available for countries with flexible labour markets, mainly the United States. Even more, in contrast to many countries in Continental Europe, the European countries for which estimations are available (the United Kingdom, Germany, Portugal and Italy) do not exhibit a large incidence of wage indexation policies or centralized collective agreements.

Spain is a suitable scenario to evaluate real wage cyclicality within a much rigid labour market. The Spanish system of collective bargaining is based on two principles that deter firms from adjusting wages along the business cycle. The first principle automatically extends any collective agreement beyond the scope of a firm to all workers in the same sector and province, even if they had not participated in the bargaining process. The second principle secures the validity of collective agreements after their expiration. Likewise, a large share of agreements (more than $60 \%$ ) include indexation clauses which trigger high inertia in firms' wage-setting decisions. Lastly, duality in the labour market insulates workers under permanent contracts (around 67$70 \%$ of the workforce with high levels of employment protection) from business cycle fluctuations.

I find weak procyclicality of real wages in Spain over the period 1988-2011. My baseline estimate is a $0.4 \%$ increase in wages in response to a $1 \%$ decline in the (lagged) unemployment rate. This estimate is the lowest among available estimates, which usually vary between 1.3 and $1.5 \%$ increase in wages in the United Statesagain for a $1 \%$ drop in the unemployment rate-and an even larger increase in wages between 2.0 and $2.2 \%$ in European countries. When I use total salaries instead of base salaries for a restricted period in which the former are available, I still obtain a low level of procyclicality at $0.6 \%$. Thus, as expected, I find real wage cyclicality is lower in a country with institutions that hinder firms to respond to business cycle fluctuations. In this line, this finding indicates that for some European countries with high-wage indexation and employment protection policies (e.g., Belgium, Austria, France and Scandinavian countries), wage cyclicality is presumably much lower than the available European estimates.

To obtain these cyclicality estimates I use a rich social security data set-Muestra Continua de Vidas Laborales (MCVL). This is an administrative data set that tracks career histories for a $4 \%$ sample of individuals who in a calendar year have any relationship with social security. For each individual, all employment and most unemployment spells are available at the daily level since 1981 or entry in social security, whichever is more recent. Thus, I can construct a monthly panel recording labour market status, some individual traits, job characteristics and wages.

This unique data set has strong advantages relative to other data sets that have been used to estimate wage cyclicality. By exploiting the high frequency in the data I can identify most labour market transitions, specially those that are of particular interest in the wage cyclicality literature (e.g. estimating cyclicality levels for job 
movers, for workers who start jobs from periods of unemployment or inactivity, or for workers who remain within an employer-employee match). Such transitions are not available in surveys with high attrition or are difficult to detect in administrative data sets with longer periodicity. Moreover, I can estimate the cyclicality of the net present values of wages in new matches over their job duration, which constitutes a key piece of information for the Mortensen-Pissarides search and matching model.

One drawback in the data set is the intermediate level of censoring in wages. I propose a simple approach to simulate wages using information on individual and job characteristics, uncensored wage observations and wage persistence estimated by exploiting the longitudinal dimension in MCVL. This is by itself one empirical contribution of the study. In the line of Haider and Solon (2006), I assume uncensored wages for a worker follow a multivariate log-normal distribution. I estimate using Tobit regressions the mean and variance of wages in each period. To approximate wage correlation coefficients between any two periods I develop an indirect inference approach. Lastly, I simulate wages only for censored observations and evaluate the fit of the simulation by comparing these simulated wages to total salaries available from income tax return data for a restricted period. Overall, the fit of the simulation is quite satisfactory.

This study contributes to the wage cyclicality literature in several aspects. First, as already mentioned, unlike wage cyclicality estimates for countries with flexible labour markets, this study provides one estimate for a rigid labour market scenario. Second, the study shows how wage cyclicality responds in a setting with high duality in employment protection. I find cyclicality for workers under temporary contracts is twice as large as for workers under permanent contracts. Thus, temporary workers carry most of the burden of wage adjustments along the cycle, while permanent workers are much less affected. Third, I present evidence of wage cyclicality decreasing consistently with the level of job tenure. I find cyclicality is much higher for newlyhired workers (those who start jobs from periods of unemployment or inactivity) than for job stayers with high levels of tenure. The availability of employer identifiers allows to calculate tenure levels with high precision and to estimate cyclicality within an employer-employee match as in Devereux (2001).

The estimated difference in wage cyclicality between newly-hired workers and job stayers is relevant for the empirical validity of the Mortensen-Pissarides search and matching model (Mortensen and Pissarides 1994; Pissarides 2000). The model has been challenged on its ability to match the observed cyclicality on vacancies and unemployment. Some studies have suggested wage rigidity as a potential solution to this so called unemployment-volatility puzzle (Hall 2005; Shimer 2005). In this model, the cyclicality of the net present value of wages in new matches is a key statistic to determine job creation (Pissarides 2009). I estimate such cyclicality for the net present value of wages in new matches and obtain a similar estimate for wages of newly-hired workers. This result, the first using actual data on monthly wages and job durations, is encouraging since the net present values of wages is rarely observed and impossible to calculate in most data sets. Overall, this finding does not give support to wage rigidity as a solution to the unemployment-volatility puzzle. 
The rest of the paper is structured as follows. Section 2 reviews some institutional aspects of the Spanish labour market. Section 3 describes the data and the approach developed to simulate wages for censored observations. Section 4 explains the estimation methodology. Section 5 presents the results. Finally, Sect. 6 concludes.

\section{Institutional aspects of the Spanish labour market}

In this section I highlight some features of the Spanish labour market that influence the response of wages to changes in economic conditions throughout the period 19882011. In particular, I focus on the system of collective bargaining and the duality in labour market contracts. The combination of these two factors makes Spain an interesting scenario to examine wage cyclicality. ${ }^{1}$

The Spanish system of collective bargaining follows the principles established in the 1980 Workers' Statute, which experienced only minor changes since its adoption until the recent labour market reform in 2012. Two main principles govern the Statute. First, the principle of automatic effectiveness states that any collective agreement of a higher level than a firm agreement is immediately extended to all firms and workers in the same sector and province. Workers do not need to be affiliated with a union or to participate in the bargaining process. Second, the ultra-activity principle guarantees the permanent validity of collective agreements after their expiration. Moreover, if the terms on a new agreement are less beneficial to workers than on the earlier one, then the new agreement can not be endorsed.

The system of collective bargaining in Spain can be characterized by its large scope, intermediate degree of centralization, substantial inertia in wage indexation and homogeneity in wage setting decisions. The rate of coverage reaches more than $80 \%$ of private sector workers despite a low rate of unionization below $15 \%$. This disparity in rates is sustained, of course, by the principle of automatic effectiveness. The bargaining process takes place mainly at the sectoral level within a provincial scope-only less than $15 \%$ of workers are subject to a firm agreement, which are frequent in large firms and negligible in firms with fewer than 200 workers. The high rate of inertia in wages is reflected in the large share of agreements (between 60 and $70 \%$ ) that incorporate indexation clauses. Collective agreements last around 2.5 years - a long duration similar to those of Scandinavian countries - and include annual wage setting policies and protection clauses in case of deviations from the inflation rate of reference.

All these features of the Spanish system of collective bargaining do not contribute to the adjustment of wages and employment levels to macroeconomic conditions or the evolution of labour demand and supply. In fact, several studies find a high

\footnotetext{
1 See Estrada and Izquierdo (2005) for a review of institutional aspects of the labour market. Bentolila et al. (2010) provide a recent description of the Spanish system of collective agreement. Dolado et al. (2002) analyze the causes and characteristics of labour market duality in Spain. The recent labour market reforms of 2010 and 2012 escape the period of analysis. Most of the changes resulting from these reforms started to take place in 2011 and specially after. More recent waves of data will help examine whether these reforms substantially affected the level of real wage cyclicality in Spain.
} 
incidence of nominal and real wage rigidities in Spain. ${ }^{2}$ Most of them exploit microdata from the Wage Dynamics Network (WDN) survey-a project sponsored by the European Central Bank that records information on the determinants of price and wage setting decisions by European firms. In this survey the share of Spanish firms that have frozen wages in the past 5 years is only $2.4 \%$, a share four times lower than the European average (9.6\%). Likewise, a substantial share of firms (55\%) apply an automatic indexation mechanism, a fraction three times larger than the European average (17\%). Cuadrado et al. (2011), using the same data set on wages as in this study but a different methodology, find evidence of a high level of real wage rigidity in Spain. In fact, their findings indicate Spain ranks fifth among 17 OECD countries only after Belgium, Sweden, Finland and France.

The duality in the Spanish labour market is the result of two hiring mechanisms with different firing costs. On one hand, workers under permanent contracts benefit from a high level of employment protection through generous severance payments and legal defense in case of a firing event. On the other hand, workers under temporary contracts have much lower severance payments and do not face legal proceedings when the contract expires. As a result, in this dual labour market, workers in permanent contracts (around 67-70\%) enjoy high protection and bargaining power, while workers in temporary contracts earn lower wages and suffer from high turnover rates and low levels of job tenure. ${ }^{3}$

This dual labour market and the restrictions imposed by a stringent system of collective bargaining hinder firms to react to changes in economic conditions by adjusting wages. ${ }^{4}$ Workers under permanent contracts benefit from wage indexation policies and high firing costs. Therefore, it is not surprising that temporary workers take most of the burden of labour market adjustments. According to the WDN survey, when Spanish firms were asked about ways to reduce costs in response to potential demand shocks, a notable share of $58 \%$ responded they would adjust by reducing temporary employment while only $10 \%$ by lowering wages (Izquierdo and Cuadrado 2009). The corresponding averages across firms in European countries show that only $22 \%$ of firms would react by reducing employment and $13 \%$ by lowering wages (Bentolila et al. 2010).

\footnotetext{
2 Nominal (downward) wage rigidities arise when there is a low incidence of wage cuts, while real (downward) wage rigidities are induced by institutional mechanisms that generate wage increments of the same order as inflation. Holden and Wulfsberg (2008) find no significant evidence of nominal wage cuts in Spain using industry-level wage data for 19 OECD countries during the period 1973-1999. Babecký et al. (2010) show wages in Spain exhibit both nominal and real (downward) rigidities using data from the Wage Dynamics Network survey in the years 2007-2008.

3 The rise in the share of temporary workers induced the government to implement reforms to mitigate the 1984 labour market liberalization policy. In 1994, the government toughened some rules for the use of temporary contracts and expanded the array of reasons for job dismissal. This reform had no effect in the aggregate share of temporary workers. Furthermore, in 1997, another reform introduced a new permanent contract with lower firing costs and social security contribution (such contract was extended and amplified in a later reform in 2001). According to Dolado et al. (2002) the net effect was a small decline in the share of temporary workers.

4 The recent labour market reforms limited the ultra-activity principle, increased decentralization of collective agreements at the firm level, decreased firing costs, and reduced workers' bargaining power by giving firms economic reasons to reduce wages. Yet, the reforms did not tackle specifically the high level of duality in the Spanish labour market.
} 


\section{Data}

The main data set used in the study is Spain's Continuous Sample of Employment Histories (Muestra Continua de Vidas Laborales or MCVL). This administrative data set is a $4 \%$ non-stratified random draw of the population of individuals related with the social security system in a calendar year. Individuals can either be working as employees or self-employeds, receiving unemployment benefits or receiving a pension. The MCVL records all changes in labour market status and job characteristics for each individual in the sample since 1981 or entry in social security, whichever is more recent. I combine seven editions of the MCVL in order to obtain a $4 \%$ sample of all individuals who appear in social security records at any time throughout 2005-2011.

Individuals enter the sample based on their anonymized social security number and remain in subsequent editions. Each new MCVL wave adds individuals who first enter the labour market and losses those who were deceased or left the country in the previous calendar year (those who stopped working remain in the sample while they receive unemployment benefits, disability benefits or a retirement pension). The unit of observation in the source data records the starting and ending date for any change in the individual's labour market status or job characteristics (including changes in occupation or remuneration within the same firm). Therefore, as long as an individual registers one day of activity with social security in any calendar year between 20052011, her complete working life history can be recovered up to 1981.

I construct for all workers monthly working life histories including their labour market status, daily wages, and some individual and main job characteristics. ${ }^{5}$ For every job spell I know the number of working days in each month, the type of occupation and contract (permanent or temporary, full-time or part-time), the 3-digit NACE sector of economic activity, and whether the individual is self-employed, a private sector employee or a public sector worker. ${ }^{6}$ Some individual characteristics like age and gender are provided while other individual variables such as level of education and country of birth are obtained from the Padrón or Municipal Register.

Monthly wages are available for all workers but some observations are censored. These wages correspond to base salaries and do not include overtime, commissions or bonuses. ${ }^{7}$ I calculate daily wages by dividing monthly wages by the number of working days in each month. Later in this section, I explain in detail how I simulate daily wages only for capped observations exploiting the panel dimension in the MCVL and data on uncensored wage observations and individual and job characteristics. I build detailed measures of cumulative labour market experience by adding up the actual number of working days in each month. Similarly, I construct a measure of job

\footnotetext{
5 In months when individuals become unemployed, I classify them as such if the amount of daily unemployment benefits exceeds the amount of daily wages in the same month. Likewise, I identify the main job as the job with the highest daily wage (and highest number of working days in case of a tie).

6 Employers assign workers into one of ten social security occupation categories. These categories aim to proxy the skills required by the job and not necessarily those acquired by the worker. Employers were required to report information on contractual conditions for all workers since 1996.

7 According to García-Pérez (2008) and Cuadrado et al. (2011) MCVL base salaries or contributions to social security are a good proxy of total salaries for a large share of the population of workers.
} 
tenure at the establishment location. This is possible since legislation forces employers to keep separate earnings' contribution accounting codes for each province in which they conduct business. Unfortunately, employers do not need to keep a unique firm identifier across provinces; hence, I cannot build a second measure of job tenure at the firm level. ${ }^{8}$

This rich administrative data set has special advantages over other data sets that have been used to estimate wage cyclicality. First, its large coverage makes it a representative sample of the Spanish labour force, as opposed to smaller surveys such as the PSID or the NLSY for the United States. ${ }^{9}$ Second, its daily frequency allows for the accurate identification of most labour market transitions, including moves to new jobs for workers who come from unemployment or periods of inactivity, job moves between firms for continuously employed workers, and long-term separations into unemployment or inactivity. These transitions are not easy to detect in annual data sets or surveys with high levels of attrition. Third, the presence of an establishment identifier makes it possible to construct precise measures of job tenure at this level and to estimate wage cyclicality within a job or employer-employee match. Finally, it is also possible to calculate the present value of wages in a new match, a key statistic for job creation in the canonical search and matching model. In fact, this is the first study that calculates such present values using actual data on job durations and wages.

\section{Sample restrictions}

The initial sample is a monthly data set of men born between 1929 and 1991 who have worked at any time between January 1988 and December 2011 (i.e., aged 20-60 during this period). I also compute wage cyclicality estimates for women and for all workers, but focus mostly on the results for males given the availability of estimates for other countries. ${ }^{10}$ I exclude periods of unemployment and spells workers spent as self-employed because wages and the number of working days are self-reported and, hence, less reliable. ${ }^{11}$ A total of 599,307 individuals and 67,335,705 monthly observations make up this initial sample.

From this initial sample, I drop observations with non-contributory occupations and missing values of occupation and establishment location, and drop individuals for whom educational attainment is missing. These restrictions reduce the sample to 549,350 individuals and 64,029,103 monthly observations. Then, I eliminate the years

\footnotetext{
8 Thus, it is not possible to include firm fixed-effects in the estimation of real wage cyclicality as in recent studies. Carneiro et al. (2012) argue that the composition and behaviour of firms might vary along different phases of the cycle, i.e., not only firms that enter or exit activity during the cycle are a selected sample, but also firms' wage-setting policies might change throughout the cycle.

9 García-Pérez (2008) tabulates worker characteristics for MCVL and for the Spanish Labour Force Survey (EPA) and finds similar population magnitudes.

10 I set 1988 as the initial year because prior to it job tenure is left-censored-recall it can be measured since 1981. Still, as I show later in the results, when I estimate wage cyclicality for workers with high levels of job tenure, I group workers with more than 6 years of tenure into a single category.

11 I also eliminate apprenticeships and job spells in agriculture, fishing, mining and household activities since non-pecuniary payments are more prevalent in these activities and the number of working days is again self-reported. These spells account only for $8.2 \%$ of the sample at this stage.
} 
in which individuals show low labour force attachment, i.e. those calendar years where individuals with less than 1 year of job tenure work less than 1 month or where individuals with more than 1 year of job tenure work less than 1 quarter. After this restriction the sample contains 538,073 individuals and 62,843,952 monthly observations.

I further restrict the sample to full-time job spells in the private sector. Earnings in the public sector are heavily regulated by the national and regional governments and only a small subset of male workers are under a part-time contract (5\% percent of observations at this stage). This leaves the final sample at 513,058 individuals and $56,107,014$ monthly observations.

\section{Job tenure categories}

I define two job tenure classifications based on establishment identifiers. In the first classification I count the number of working days accumulated in an establishment throughout a worker's career. When the worker switches jobs the level of job tenure resets to zero in the new establishment. If he later returns to an earlier job or establishment, the tenure count starts from its former level, i.e., the level of tenure when he left that job. In the second classification a return to a previous job or establishment is considered a new spell. Thus, by construction job tenure levels can not exceed those in the former classification. More important, the first tenure classification allows to estimate the cyclicality of wages for workers within a match, i.e., for those workers who start a job and have not worked in the firm before.

For each job tenure classification I construct six tenure categories. I divide workers who start a new job into newly-hireds - those who come from periods of unemployment or inactivity - and job-movers - those who change jobs in two consecutive months. Workers remain under these categories during their first year of tenure. ${ }^{12}$ The other tenure categories are the following: 1-2, 2-4, 4-6 years and more than 6 years.

Column (1) in Table 1 shows the share of observations in each tenure category under both classifications. Newly-hireds and job-movers account for at least $25 \%$ of all observations while workers with more than 4 years of job tenure comprise a greater share above $41 \%$. The share of observations in the first year of tenure is larger than in other countries. For instance, this share accounts for $16.4 \%$ of annual observations in Portugal throughout 1986-2007 (Carneiro et al. 2012). ${ }^{13}$ This polarization in the level of job tenure mirrors the duality in the Spanish labour market referred to in the previous section. Column (2) reveals that the use of temporary contracts is predominant

\footnotetext{
12 I have been extremely careful in identifying these two job tenure categories. Given the high frequency in the MCVL data, one can often find jobs with very short durations (e.g. less than a week). I exclude all jobs that last less than one month since they are likely to involve piecework or are unusual in the working lives of most individuals. Also, I can not classify all job starts appropriately. In few cases a worker may start a job, leave it for a while (e.g. 2 months) and return later. I leave out all jobs in which a worker does not remain in the establishment during the first two months, so that he is not classified as newly-hired or job-mover during his first year of tenure, but can possibly be classified into other tenure categories as he remains in the job.

13 Using a similar method to identify newly-hired workers, Haefke et al. (2013) report that the share of newly-hireds represents around $8 \%$ of the total number of workers in the United States in an average quarter between 1979 and 2006.
} 
Table 1 Job tenure categories

\begin{tabular}{llll}
\hline & $(1)$ & $(2)$ & $(3)$ \\
\cline { 2 - 4 } & $\begin{array}{l}\text { Share in } \\
\text { sample (\%) }\end{array}$ & $\begin{array}{l}\text { Share under temporary } \\
\text { contract }(\%)\end{array}$ & $\begin{array}{l}\text { Median monthly } \\
\text { wages }(€)(\%)\end{array}$ \\
\hline Classification 1 & 11.6 & & 1,244 \\
Newly-hireds & 13.1 & 82.0 & 1,422 \\
Job-movers & 13.9 & 65.4 & 1,448 \\
1-2 years & 17.5 & 47.2 & 1,571 \\
2-4 years & 11.2 & 27.0 & 1,717 \\
4-6 years & 32.8 & 16.1 & 2,115 \\
More than 6 years & & 5.6 & 1,252 \\
Classification 2 & 14.8 & 82.2 & 1,428 \\
Newly-hireds & 12.8 & 64.6 & 1,473 \\
Job-movers & 14.1 & 43.0 & 1,621 \\
1-2 years & 17.0 & 21.7 & 1,783 \\
2-4 years & 10.6 & 11.3 & 2,159 \\
4-6 years & 30.6 & 3.7 & \\
More than 6 years & & $1988-2011$, except & \\
\hline
\end{tabular}

Variables are sample means or medians throughout 1988-2011, except for the share of workers under temporary contract which is restricted to the period 1996-2011. The numbers of monthly observations for classification 1 and 2 of job tenure categories are 54,883,039 and 54,067,567, respectively. Monthly wages are expressed in December 2011 euros

among workers who start a job-greater than $82 \%$ for newly-hireds and somewhat lower for job-movers at $65 \%{ }^{14}$ This high incidence of temporary work may increase turnover rates in the labour market and generate dispersion in job durations of new matches - in the sample, using the first tenure classification, the 25 th percentile and the median of the distribution of job duration of new matches are quite low at 4 and 9 months, respectively, while the mean and 75th percentile are much larger at 25 and 27 months, respectively. Column (3) also highlights large raw wage differentials among job tenure categories.

\section{Simulating wages for censored observations}

The MCVL reports data on monthly wages throughout 1988-2011, but these are censored for some workers. In particular, 16.1 and $1.5 \%$ of daily wage observations are top- and bottom-coded, respectively (recall I divide monthly wages by the total num-

\footnotetext{
14 When I restrict the newly-hired category only to the first three months of job tenure instead of the first year, the incidence of temporary contracts among newly-hireds increases to $88 \%$. Therefore, between 1996 and 2011, almost nine out of ten new jobs for workers coming from periods of unemployment or inactivity were set under a temporary contract. The incidence of temporary contracts also increases to $73 \%$ for job-movers when I restrict this category only to the first three months.
} 
ber of working days in each month). In this subsection I explain how I simulate daily wages for the $17.6 \%$ of observations that are censored.

Censoring bounds vary by type of occupation on an annual basis. Since these bounds are not available in the MCVL, I gathered annual bulletins from Spain's official newspaper Boletín Oficial del Estado (BOE) which document censoring bounds for each type of occupation. I checked consistency of these bounds by plotting monthly wage densities in MCVL for each occupation in a given year. Overall, censored observations in MCVL can be easily detected using the information from the BOE bulletins.

Subsequently, I estimate 960 Tobit regressions by groups of age, occupation and year ( 4 age groups $\times 10$ types of occupation $\times 24$ years) in which the dependent variable is log daily wages expressed in December 2011 euros. I define four age groups in 10-year-age intervals between 20 and 60. As explanatory variables I include age and sets of indicator variables for gender, level of education, temporary contract, part-time contract, province of workplace, and month. Given that my baseline model to estimate wage cyclicality incorporates a worker fixed-effect, this imputation should reflect an individual-specific component of the wage. Following Card et al. (2013) on their wage imputation for German social security data, I exploit the panel dimension in the MCVL by including the worker's mean of log daily wages over his career (excluding the current wage) and the fractions of top or bottom censored wage observations over his career (again excluding the current censoring status). I calculate daily top and bottom censoring bounds by dividing monthly bounds by the number of calendar days in each month. Daily wages that exceed daily censoring bounds are flagged as top-coded and viceversa.

After these Tobit estimations, I simulate daily wages for censored observations as follows:

$$
\hat{W}_{i j t}=x_{i j t}{ }^{\prime} \hat{\gamma}+\hat{\sigma} \varepsilon_{i j t},
$$

where $\hat{W}_{i j t}$ is the simulated log daily wage for individual $i$ in occupation $j$ at year $t$, $x_{i j t}$ is a vector of individual and job characteristics including the mean of log daily wages and the fraction of censored wage observations in all other periods, $\hat{\gamma}$ and $\hat{\sigma}$ are estimated parameters, and $\varepsilon_{i j t}$ is an i.i.d shock. However, as shown by studies that exploit data on career-long earnings histories, earnings exhibit great persistence (Bjorklund 1993; Haider and Solon 2006). Thus, I exploit again the panel dimension in the MCVL to introduce persistence in wage shocks.

To this end I follow the methodology proposed by Haider and Solon (2006). The main assumption is that the joint distribution of uncensored log daily wages for an individual is multivariate normal. Hence, wages throughout the period of interest 1988-2011 can be fully characterized by the mean and variance of log daily wages in each period-estimated in Eq. (1) — and the cross-year autocorrelations of log daily wages for every pair of years. ${ }^{15}$ Haider and Solon (2006) estimate autocorrelations between pairs of years using a bivariate Tobit maximum-likelihood estimator. Instead, I use a more simple approach based on indirect inference to compute cross-year autocorrelations.

\footnotetext{
15 Log daily wages follow a multivariate normal distribution also within each of the ten occupation categories. For simplicity and from now on I omit index $j$ referring to type of occupation.
} 
The approach can be summarized in four steps. First, I estimate a regression coefficient for every pair of (standardized) log daily wages of the same worker $i$ in two different years. This estimation is carried out only for uncensored wage observations. I label this regression coefficient $\hat{\lambda}^{*} .{ }^{16}$

Second, I exploit the multivariate normality assumption to generate log daily wages for worker $i$ in year $t+h$ conditional on his observed wage in year $t$, the relevant censoring daily bounds and a value for the correlation coefficient $\rho$. Equation (2) shows how to generate wages in year $t+h$ based on a bivariate normal distribution of wages in years $t$ and $t+h$ :

$$
\begin{aligned}
& \tilde{W}_{i, t+h}, \tilde{W}_{i t} \sim N\left(\left(\begin{array}{l}
0 \\
0
\end{array}\right),\left(\begin{array}{ll}
1 & \rho \\
\rho & 1
\end{array}\right)\right), \\
& \mathbb{E}\left(\tilde{W}_{i, t+h} \mid \tilde{W}_{i t}, \tilde{a}_{t+h} \leqslant \tilde{W}_{i, t+h} \leqslant \tilde{b}_{t+h}\right)=\rho \tilde{W}_{i t}+\sqrt{1-\rho^{2}}\left[\frac{\phi\left(\frac{\tilde{a}_{t+h}-\rho \tilde{W}_{i t}}{\sqrt{1-\rho^{2}}}\right)-\phi\left(\frac{\tilde{b}_{t+h}-\rho \tilde{W}_{i t}}{\sqrt{1-\rho^{2}}}\right)}{\Phi\left(\frac{\tilde{b}_{t+h}-\rho \tilde{W}_{i t}}{\sqrt{1-\rho^{2}}}\right)-\Phi\left(\frac{\tilde{a}_{t+h}-\rho \tilde{W}_{i t}}{\sqrt{1-\rho^{2}}}\right)}\right],
\end{aligned}
$$

where $\tilde{W}_{i t}$ are the standardized uncensored log daily wages for individual $i$ in year $t, \rho$ is the correlation coefficient, and $\tilde{a}_{t+h}$ and $\tilde{b}_{t+h}$ are the standardized lower and upper daily bounds applicable in year $t+h$, respectively. Since the only unknown in $\mathbb{E}\left(\tilde{W}_{i, t+h}\right)$ is the value of $\rho$-the cross-year autocorrelation of interest-based on a grid of 40 values of $\rho$ from 0 to 0.975 on 0.025 intervals, I generate $\mathbb{E}\left(\left.\tilde{W}_{i, t+h}\right|_{\rho=\rho_{k}}\right)$ where $k=1, \ldots, 40$.

Third, I regress each generated $\mathbb{E}\left(\left.\tilde{W}_{i, t+h}\right|_{\rho=\rho_{k}}\right)$ on $\tilde{W}_{i t}$ only for uncensored observations and obtain a regression coefficient $\hat{\lambda}_{k}$. The optimal value of the cross-year autocorrelation $\rho_{k}^{*}$ is the $\rho_{k}$ which minimizes the absolute distance between $\hat{\lambda}^{*}$ and any $\hat{\lambda}_{k}$. Thus, if log daily wages for worker $i$ follow a multivariate normal distribution, I choose the $\rho_{k}^{*}$ that best replicates the observed correlation for uncensored daily wages in the data. I construct variance-covariance matrices $(24 \times 24)$ for each occupation with the optimal $\rho_{k}^{*}$ values calculated for every pair of years throughout 1988-2011.

Finally, I simulate wages only for censored observations as follows:

$$
\hat{W}_{i j t}=x_{i j t}{ }^{\prime} \hat{\gamma}+\hat{\sigma} \cdot \hat{p}_{j t}{ }^{\prime} \xi_{i j t}
$$

where all variables are the same as in Eq. (1), but now $\hat{p}_{j t}$ is a row vector $(1 \times 24)$ of the Cholesky decomposition of the estimated variance-covariance matrix and $\xi_{i j t}$ is a vector of random shocks. Since I know whether daily wages are originally top- or

\footnotetext{
16 To take advantage of the monthly frequency of wages in the MCVL data, for every pair of years I regress daily wages (monthly wages divided by the number of working days) for the same worker in a given month. For example, I regress daily wages for worker $i$ in May 1998 on daily wages for worker $i$ in May 1997. Thus, an individual who works throughout the calendar year contributes with twelve observations to the estimation of the regression coefficient. This approach does not lose any valuable information in the data. From now on, all references to a particular year $t$ refer to all the months where individual $i$ works in year $t$.
} 
bottom-coded, I force simulated wages to be above or below the corresponding bound, respectively. ${ }^{17}$

The fit of the simulation can be tested for the period 2004-2011 in which uncensored earnings from income tax data have been merged to MCVL. These earnings include all labour income (salaries plus overtime and bonuses) and are matched to MCVL based on both employee and employer identifiers separately for every job in a calendar year. Average daily job earnings can be obtained by dividing annual labour job earnings by the number of working days in that job in a calendar year obtained from MCVL. The Appendix presents details on the fit of the simulation. In general, I am able to match the shape of the upper tail of the earnings distribution, even for the group of high-skilled workers who are top-coded beyond the 52nd percentile. Moreover, the degree of persistence observed in labour earnings is remarkably similar to the one I obtain in the MCVL after simulating censored observations. These results increase the odds that the distribution of simulated daily wages can accurately approximate the distribution of actual daily labour earnings in the period 1988-2003.

\section{Estimation methodology}

In order to estimate wage cyclicality I use a level wage equation of the following form:

$$
\ln w_{i t}=\alpha_{i}+x_{i t}{ }^{\prime} \beta+\delta_{1} U_{t}+\delta_{2} T+\epsilon_{i t},
$$

where $\ln w_{i t}$ is the log real daily wage of worker $i$ in period $t$ (a year-month pair), $\alpha_{i}$ is a worker fixed-effect, $x_{i t}$ are individual and job characteristics, $U_{t}$ is the national civilian unemployment rate (used as a cyclical variable), $T$ is a linear time-trend and $\epsilon_{i t}$ is the error term with zero mean and constant variance. The previous literature has emphasized the need to address composition bias resulting from various types of individuals working in different phases of the business cycle (Solon et al. 1994). To this end, I introduce worker fixed-effects to capture time-invariant unobserved individual heterogeneity.

The most common solution used to address such composition bias has been to estimate a wage regression in first differences (Bils 1985; Solon et al. 1994; Shin 1994; Devereux 2001; Devereux and Hart 2006). However, this strategy restricts the sample to individuals who work in two consecutive periods-or years given that most studies are based on annual or bi-annual surveys. For this reason, studies that estimate wage cyclicality for newly-hired workers - or any group of workers with weak labour force attachment-run a wage equation in levels (Carneiro et al. 2012; Haefke et al. 2013; Kudlyak 2013). By following this approach, I can exploit the full sample of

\footnotetext{
${ }^{17}$ In particular, if $k_{b}=\Phi\left[\left(b_{i j t}-x_{i j t}{ }^{\prime} \hat{\gamma}\right) / \hat{\sigma}\right]$, where $\Phi$ represents the standard normal density, $b_{i j t}$ is the daily wage level at which top censoring occurs and $u \sim U[0,1]$ is a uniform random variable, then I define $\xi=\Phi^{-1}\left[k_{b}+u \times\left(1-k_{b}\right)\right]$. Likewise, if $k_{a}=\Phi\left[\left(a_{i j t}-x_{i j t}{ }^{\prime} \hat{\gamma}\right) / \hat{\sigma}\right]$, where $a_{i j t}$ is the daily wage level at which bottom censoring occurs, then I define $\xi=\Phi^{-1}\left[k_{a} \times u\right]$. This procedure does not necessarily makes all censored earnings to be above or below the corresponding bounds-given the presence of $\hat{p}_{j t}$ in Eq. (3)—, yet empirically, only $0.99 \%$ and $0.76 \%$ of wage observations remain top and bottom-coded, respectively.
} 
workers including job stayers, newly-hired workers and job-movers. Also, given the high frequency in the data and the sample restrictions considered, all individuals appear more than once, so I do not lose observations when introducing worker fixed-effects. ${ }^{18}$

In the specification of Eq. (4) the standard error of the estimated coefficient of interest, $\delta_{1}$, is substantially underestimated in the presence of a year-specific error, since all workers in period $t$ face the same level of unemployment (Moulton 1986). For this reason, like in previous studies (Solon et al. 1994; Shin 1994; Devereux 2001), I adopt a two-stage estimation method and transform the specification in Eq. (4) in the following two equations:

$$
\begin{aligned}
\ln w_{i t} & =\alpha_{i}+x_{i t}{ }^{\prime} \beta+\sum_{t=1}^{T} \eta_{t} D_{t}+\psi_{i t}, \\
\hat{\eta}_{t} & =\theta_{1} U_{t}+\theta_{2} T+v_{t} .
\end{aligned}
$$

Equation (5) now includes a set of indicator variables $\eta_{t}$ for each year-quarter pairwages are observed monthly but the unemployment rate is at the quarterly level-that capture in an unrestricted way all temporal variation in wages net of observed and (time-invariant) unobserved individual characteristics. In the second stage, Eq. (6), I regress the estimated year-quarter indicators $\hat{\eta}_{t}$ on the unemployment rate and a linear time trend. Therefore, the standard error of the new coefficient of interest, $\theta_{1}$, is now free from the aggregate bias present in Eq. (4). ${ }^{19}$

The cyclicality coefficient $\theta_{1}$ measures the semi-elasticity of wages with respect to the unemployment rate. Most studies using micro-data on wages use the unemployment rate as the preferred proxy of the economic cycle, following the lead of Bils (1985). A negative estimated value for $\theta_{1}$ would indicate wages are procyclical. I multiply log wages by 100 so that $\theta_{1}$ approximates the percentage change in wages in response to a one percentage point increase in the unemployment rate.

\section{Results}

\section{Baseline estimates of wage cyclicality}

I begin by estimating the two-stage method described in Eqs. (5) and (6) for different groups. In the first stage I regress log daily wages (deflated using the Consumer Price Index and expressed in December 2011 euros) on worker fixed-effects, quartics of experience and job tenure, an indicator for temporary contract and a set of occupation

\footnotetext{
18 Note that given the monthly frequency in the data I could still estimate cyclicality for newly-hired workers using first differences. In this setup, I would be restricting the sample to those who are currently working, were employed in the same quarter during the past year, but faced periods of unemployment or inactivity before entering the current job. Still, I rather prefer to estimate wage cyclicality in levels using the full sample.

19 One alternative is to estimate Eq. (4) using robust-clustered standard errors by year-quarter. However, when worker fixed-effects are introduced this is not plausible as workers are observed in different periods. Carneiro et al. (2012) provide a simple method to obtain standard errors in a one-step estimation.
} 
Table 2 Baseline estimates of wage cyclicality

\begin{tabular}{llll}
\hline & $\begin{array}{l}\text { Cyclical indicator: } \\
\text { unemployment } \\
\text { rate (levels) }\end{array}$ & $\begin{array}{l}\text { Cyclical indicator: } \\
\text { unemployment rate } \\
\text { (first-differences) }\end{array}$ & $\begin{array}{l}\text { Observations } \\
\text { (first stage) }\end{array}$ \\
\hline (1) Sample: male workers & $-0.379(0.043)^{* * *}$ & & $56,107,014$ \\
(2) Sample: all workers & $-0.332(0.043)^{* * *}$ & & $83,151,939$ \\
(3) Sample: female workers & $-0.221(0.048)^{* * *}$ & & $27,044,925$ \\
(4) Sample: male workers & & $-0.399(0.077)^{* * *}$ & $46,131,112$ \\
\hline
\end{tabular}

Each coefficient is a separate second stage regression of the estimated year-quarter coefficients on the yearly-lagged quarterly unemployment rate. All second stage regressions have 96 quarterly observations (1988:1 to 2011:4) and include a constant term, a linear time trend and quarter indicators. In row (4) the first stage regression is in first-differences and the second stage regresses the estimated year-quarter coefficients on the lagged annual change in the quarterly unemployment rate ( 92 observations). ${ }^{* *}, * *$, and * indicate significance at the 1,5 , and 10 percent levels

indicators and year-quarter indicators. ${ }^{20}$ In the second stage I regress the estimated year-quarter indicator coefficients on the yearly-lagged quarterly unemployment rate, a linear time trend and quarter indicators. I include the lagged unemployment rate given that in Spain most wages are set 1 year in advance. ${ }^{21}$ I report only results for the coefficient of interest, $\theta_{1}$, the semi-elasticity of real wages with respect to the (lagged) unemployment rate.

Row (1) in Table 2 shows evidence of weak real wage procyclicality for men in Spain. A one percentage point decline in the unemployment rate is associated with a small increase in real wages of $0.38 \%$. In row (4) I estimate wage cyclicality for men but using first-differences in both stages, as in Solon et al. (1994) and Devereux (2001). Cyclicality increases only marginally and is not statistically different from the baseline estimate in row (1). I have also carried out alternative second stage estimations by using the unemployment rate for men, including a quadratic trend, using other lags of unemployment or estimating a one-stage specification as in Eq. (4). The semielasticity varies little within a range from 0.372 to 0.391 .

Figure 1 plots the relationship between year-quarter coefficients (solid line) and the yearly-lagged quarterly unemployment rate (dashed line). Specifically, the left axis shows the residuals of a regression of the estimated year-quarter coefficients on a linear trend and quarter indicators. A clear negative relationship holds between both variables during the initial years until the early 2000s when the (detrended) year-

\footnotetext{
20 I use this set of regressors in all other estimations. I have also included 3-digit NACE sector indicators and province workplace indicators with minor differences in the second stage results. Unless stated otherwise, I always use the first job tenure definition (a worker keeps his level of job tenure when he returns to a prior establishment).

21 As stated in Sect. 2, collective agreements may last several years but include annual wage setting policies. Using firm-level data from the Wage Dynamics Network (WDN) Project, Babecký et al. (2010) report that firm-level indexation in Spain is widespread and often automatic (around $55 \%$ of firms apply some automatic indexation mechanism, the second largest share after Belgium). Likewise, using the same survey, Druant et al. (2012) document that $84 \%$ of firms in Spain change wages only once a year (the second largest share among the 15 European countries examined).
} 


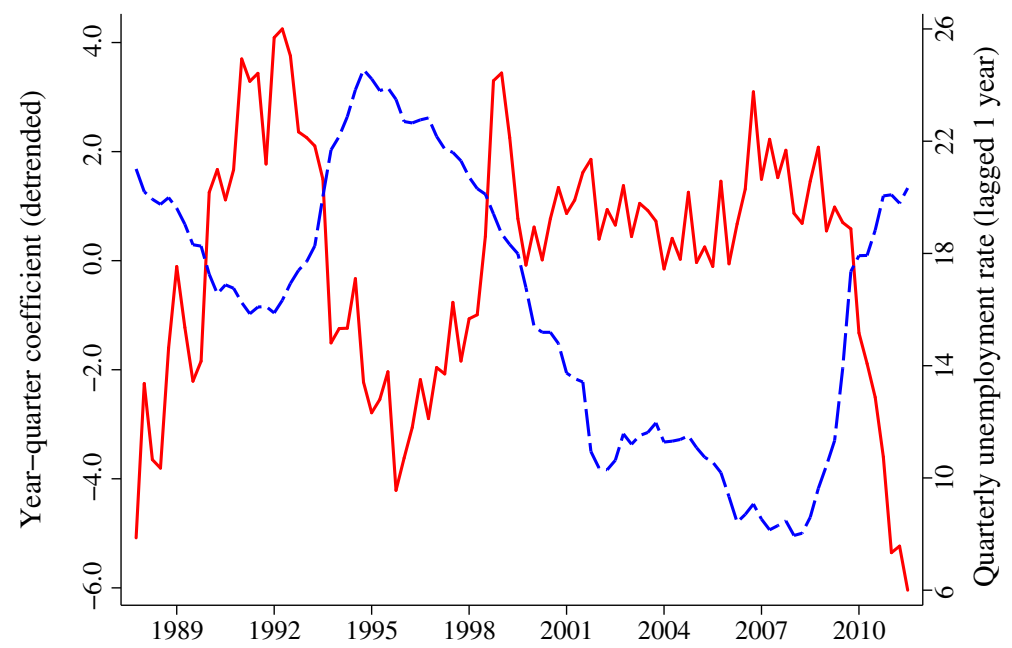

Fig. 1 Year-quarter coefficients and lagged unemployment rate

quarter coefficients become flat and stop responding to the falling levels of (lagged) unemployment. The decline of wages during this last recession is substantial and presumably would be larger when more recent years are considered. To test for differential responses of real wages to positive and negative changes in the unemployment rate, I modify the second stage and estimate annual changes in the year-quarter coefficients on positive and negative (lagged) changes in the quarterly unemployment rate, a linear trend and quarter indicators. Confirming the patterns observed in Fig. 1, I find that real wages respond to positive changes in the lagged unemployment rate (semi-elasticity of -0.482 , s.e. 0.113 ) but do not respond to negative changes in the unemployment rate (semi-elasticity of -0.136 , s.e. 0.194 ).

Similar to previous studies [see Solon et al. (1994)], the estimate in row (3) of Table 2 indicates that the degree of cyclicality for women is much lower at $0.26 \%$ (the difference with the men cyclicality estimate being significant at the $5 \%$ level). One potential explanation is that women in Spain may have a more elastic short-run labour supply than men, so that they experience more employment variation along the cycle and less variation in wages. ${ }^{22}$ In fact, compositional bias seems to matter more for women than for men. When I estimate Eqs. (5) and (6) without including worker fixed-effects and occupation indicators in the first stage, the semi-elasticity for men drops from 0.379 to 0.292 while for women the drop is much larger from 0.221 to 0.054 losing statistical significance. Therefore, the skill composition of women varies more along the cycle so that presumably low-skilled women are more affected by unemployment during the low phases.

The level of real wage cyclicality I find is not far from the one obtained by Bentolila et al. (2010). Using micro-data on collective agreements over the period 1990-2007

\footnotetext{
22 One indicator that points in this direction is the substantial difference in the fractions of women $(25.8 \%)$ and men $(6.3 \%)$ under a part-time contract between 1996 and 2011.
} 
they estimate a regression of nominal wage increments on the lagged annual changes of the regional unemployment rate and sectoral productivity, and the inflation rate (considering positive and negative deviations from the rate of reference). They also include some characteristics of collective agreements as controls. They find that a one percentage point decline in the unemployment rate is related to an increase of wages of $0.24 \%$, but only for newly-signed agreements.

The estimated level of real wage cyclicality $(0.38 \%)$ is by far the lowest among studies that use worker-level data for developed countries. Pissarides (2009) summarizes results of most available studies. For the United States a drop of one percentage point in the unemployment rate is correlated with a real wage increment of 1.3-1.5\%. For European countries (United Kingdom, Germany, Italy and Portugal) the estimated real wage cyclicality is even greater at 2.0-2.2 \%. However, based on the results of the International Wage Flexibility Project and the Bank of Spain [(see Cuadrado et al. (2011)], none of these European countries exhibits a high degree of real wage rigidity. Spain ranks fifth in such ranking after countries with extensive wage indexation (Belgium, Sweden, Finland and France), while countries such as Germany and Italy have low levels of real wage rigidity. ${ }^{23}$ Therefore, the fact that estimated levels of real wage cyclicality in Europe are higher than initially expected may be driven by the selected pool of countries for which estimations are available.

\section{Wage cyclicality for selected samples}

One potential reason for the low level of real wage cyclicality I find is the use of base salaries. If firms compensate workers during expansions by offering bonuses aside from the base salary (Devereux, 2001), then the baseline estimate would be a lower bound. ${ }^{24}$ For this reason I estimate real wage cyclicality using total salaries (all labour income) from income tax data for the period 2004-2011. Although the period is relatively short, it exhibits enough quarterly variation in wages and unemployment as it coincides with a period of economic expansion and the great recession. Rows (1) and (2) in Table 3 indicate that the semi-elasticity of wages with respect to the unemployment rate is larger when using total salaries (0.61 vs. 0.46). If I extrapolate my baseline estimate of 0.38 over the period 1988-2011, then the new estimate of real wage cyclicality is around 0.50 . Still, it reflects a much lower level of cyclicality than in other countries.

Row (3) in Table 3 estimates real wage cyclicality using only uncensored wages in MCVL and, hence, excludes mainly those workers in the upper tail of the wage distribution. The lower estimate obtained (0.31) suggests that real wages are more cyclical for high-skilled workers. Both low- and high-skilled workers benefit from wage setting policies in collective agreements, but the latter may profit more during

\footnotetext{
23 See also Dickens et al. (2007); Babecký et al. (2010).

24 Workers and firms may agree to also increase the number of hours of work and, hence, the relevant wage measure becomes the hourly wage rate including overtime. Unfortunately, the MCVL does not provide information on the number of working hours.
} 
Table 3 Wage cyclicality for selected samples

\begin{tabular}{llll}
\hline & $\begin{array}{l}\text { Cyclical indicator: } \\
\text { unemployment } \\
\text { rate (levels) }\end{array}$ & $\begin{array}{l}\text { Estimation } \\
\text { period }\end{array}$ & $\begin{array}{l}\text { Observations } \\
\text { (first stage) }\end{array}$ \\
\hline (1) Sample: total salaries & $-0.608(0.043)^{* * *}$ & $2004: 1-2011: 4$ & $20,521,457$ \\
(2) Sample: base salaries & $-0.464(0.056)^{* * *}$ & $2004: 1-2011: 4$ & $22,981,470$ \\
(3) Sample: uncensored base salaries & $-0.306(0.042)^{* * *}$ & $1988: 1-2011: 4$ & $46,264,191$ \\
(4) Sample: permanent contract & $-0.274(0.046)^{* * *}$ & $1996: 1-2011: 4$ & $41,487,318$ \\
(5) Sample: temporary contract & $-0.572(0.037)^{* * *}$ & $1996: 1-2011: 4$ & $14,619,696$ \\
(6) Sample: large firms ( $\geqslant 200$ workers) & $-0.424(0.078)^{* * *}$ & $2005: 1-2011: 4$ & $4,257,803$ \\
(7) Sample: small firms (5-199 workers) & $-0.470(0.068)^{* * *}$ & $2005: 1-2011: 4$ & $9,268,264$ \\
\hline
\end{tabular}

Each coefficient is a separate second stage regression of the estimated year-quarter coefficients on the yearly-lagged quarterly unemployment rate. All second stage regressions include a constant term, a linear time trend and quarter indicators. Rows (1) and (2) contain 32 quarterly observations (2004:1-2011:4), rows (4) and (5) contain 64 quarterly observations (1996:1-2011:4), rows (6) and (7) have 28 quarterly observations (2005:1-2011:4) and row (3) has 96 quarterly observations (1988:1 to 2011:4). ${ }^{* * *},{ }^{* *}$, and ${ }^{*}$ indicate significance at the 1,5 , and 10 percent levels

expansionary periods given their greater bargaining power. Overall, the cyclicality difference between the baseline estimate and the one using only uncensored observations confirms the need to address the censoring issue in MCVL.

Next, I examine real wage cyclicality for workers under different contract types. Rows (4) and (5) in Table 3 show that wage cyclicality of workers under a temporary contract exceeds that of workers under a permanent contract by a factor of two. Workers under permanent contracts enjoy higher levels of employment protection and are more likely to benefit from collective agreements that include wage indexation clauses. In contrast, workers with temporary contracts face a much higher level of real wage cyclicality that is similar to workers in countries with more flexible labour markets.

Finally, I analyze how real wage cyclicality varies by firm size. As mentioned in Sect. 2, the wage bargaining process mostly occurs at the sectoral level with the exception of large firms that often maintain firm-level agreements. The MCVL provides information on the number of workers in the establishment but only for existing firms in each MCVL wave, i.e., this information is not available for establishments that exited before $2005 .{ }^{25}$ In rows (6) and (7) I estimate real wage cyclicality for workers in large establishments (200 or more workers) and for workers in smaller establishments (5-199 workers). Although the point estimate suggests that workers in large firms experience a lower level of real wage cyclicality, the difference between both estimates is not statistically significant.

\footnotetext{
25 Also, given that there is no unique identifier for firms with several establishments across provinces, some establishments with a small number of workers may actually belong to large firms.
} 
Table 4 Wage cyclicality for job tenure categories

\begin{tabular}{llll}
\hline & $\begin{array}{l}\text { Job tenure } \\
\text { (classification 1) }\end{array}$ & $\begin{array}{l}\text { Job tenure } \\
\text { (classification 2) }\end{array}$ & $\begin{array}{l}\text { Job tenure } \\
\text { (classification 1, } \\
\text { excl. migrants) }\end{array}$ \\
\hline Newly-hired workers & $-0.691(0.058)^{* * *}$ & $-0.614(0.057)^{* * *}$ & $-0.689(0.059)^{* * *}$ \\
Job-movers & $-0.505(0.054)^{* * *}$ & $-0.501(0.054)^{* * *}$ & $-0.497(0.054)^{* * *}$ \\
1-2 years & $-0.532(0.057)^{* * *}$ & $-0.507(0.057)^{* * *}$ & $-0.532(0.058)^{* * *}$ \\
2-4 years & $-0.358(0.053)^{* * *}$ & $-0.338(0.053)^{* * *}$ & $-0.357(0.053)^{* * *}$ \\
4-6 years & $-0.293(0.045)^{* * *}$ & $-0.273(0.044)^{* * *}$ & $-0.293(0.044)^{* * *}$ \\
More than 6 years & $-0.225(0.039)^{* * *}$ & $-0.215(0.039)^{* * *}$ & $-0.227(0.038)^{* * *}$ \\
Observations (first stage) & $32,929,823$ & $32,440,539$ & $30,343,084$ \\
Lagged unemployment rate (levels) & Yes & Yes & Yes \\
\hline
\end{tabular}

Each coefficient is a separate second stage regression of the estimated interaction between tenure category and year-quarter coefficients on the yearly-lagged quarterly unemployment rate. All second stage regressions have 96 quarterly observations (1988:1 to 2011:4) and include a constant term, a linear time trend and quarter indicators. I randomly drop $40 \%$ of observations in the first stage given the large number of coefficients that need to be estimated. ${ }^{* *},{ }^{* *}$, and ${ }^{*}$ indicate significance at the 1,5 , and 10 percent levels

\section{Wage cyclicality by tenure category}

The employer-employee setup in MCVL allows to estimate wage cyclicality for stayers within a match. Also, in contrast to other data sets, newly-hired workers and jobmovers can be detected with more precision. In Table 4 I estimate real wage cyclicality for the tenure categories described in Sect. 3. For this purpose, I modify Eq. (5) by including indicators for tenure categories and interactions between these indicators and year-quarter indicators. Now, the second stage (Eq. 6) regresses the estimated yearquarter indicator coefficients for each tenure category on the yearly-lagged quarterly unemployment rate.

Column (1) presents cyclicality measures using the first job tenure classification, i.e., a worker accumulates tenure in a job and keeps that level if he eventually returns in the future. Real wage cyclicality declines consistently with level of tenure. For instance, a drop of one percentage point in the unemployment rate is associated with a $0.69 \%$ increase in wages for newly-hired workers, a smaller increase of $0.36 \%$ for workers with tenure between 2 and 4 years, and an even smaller increase of $0.23 \%$ for workers with more than 6 years of tenure. In column (2) I use the alternative job tenure classification in which all returns to previous jobs are classified as new spells. The cyclicality estimates decline also with the level of tenure but are slightly lower than those in column (1), particularly for newly-hired workers. Therefore, when comparing both estimates, real wage cyclicality is, as expected, greater for newly-hired workers who start a new job in which they have not acquired any level of tenure in the past.

I have performed several alternative estimations. In column (3) I restrict the sample of newly-hireds and job-movers to those who do not migrate across provinces-recall establishment identifiers are unique within a province but a main firm identifier is not provided. In this way, I eliminate newly-hired and job-mover spells that may actually correspond to within-firm relocations. The estimated semi-elasticities for both newly- 
hireds and job movers remain unaffected. In another estimation (not shown), I have limited duration of newly-hired and job-mover spells to three months while including a separate tenure category between 4 months and 1 year. The estimated cyclicality levels for newly-hired workers and job-movers are virtually identical. Lastly, results in the second stage regression for newly-hired workers do not drop substantially if I replace the yearly-lagged quarterly unemployment rate by the current unemployment rate. The estimated real wage cyclicality falls only by $15 \%$ while it declines by almost half for workers with more than 6 years of tenure. Thus, newly-hired workers appear to be the group that is most affected by current economic conditions.

Overall, the wages of workers who enter new jobs or matches-specially newlyhireds or those who come from periods of unemployment or inactivity - are the ones more exposed to the economic cycle. This is consistent with the evidence summarized in Pissarides (2009) and the findings of Haefke et al. (2013). However, the magnitude of the response again does not lie in the range of earlier estimates. A consensus estimate is that a percentage point decline in the unemployment rate is related to a real wage increment in new matches of $3 \%$. Hence, the cyclicality estimate I find for newlyhired workers is much lower than the level found for other countries, though it is still substantially larger than the wage cyclicality of stayers.

\section{Cyclicality of the net present values of wages}

The available estimates of wages in new matches being more cyclical than wages of job stayers have contributed to the discussion of wage rigidities and fluctuations of unemployment and vacancies along the cycle. Hall (2005) and Shimer (2005) argue that the Mortensen-Pissarides canonical search and matching model can not account for the observed cyclical volatility of unemployment and vacancies. They propose wage rigidity as a potential solution to this so called unemployment-volatility puzzle (Pissarides 2009).

Pissarides (2009) shows that the wage flexibility that is relevant for the model to amplify unemployment fluctuations is the one in new matches. In fact, in this model, the job creation condition depends on the difference between the expected productivity and cost of labour in new matches, while the level of wage flexibility in ongoing jobs becomes irrelevant. Using available estimates of the cyclicality in new matches, he concludes that wages in new matches are as cyclical as productivity. However, given that job creation is a forward-looking decision, the statistic that is of real interest is not necessarily the wage cyclicality in new matches but the one in the net present of value of wages over the duration of these new matches.

To this end, I calculate the net present value (NPV) of wages for each new match in period $t$ by adding up discounted wages along the duration of the match. I use an annual discount rate of $5 \%$. However, the NPV of wages for matches of different duration can not be compared directly. For this reason, I calculate both the equivalent annuity, i.e., the equivalent monthly wage along the duration of the match, and the NPV of wages divided by its duration. Then, I proceed to estimate the cyclicality of these measures using the two-stage method described in Eqs. (5) and (6), but replacing log wages in the first stage by any of the two net present values. In this setup I still address 
Table 5 Cyclicality of net present value of wages

(1)

Estimation period (1988:1-2011:4)

$-0.766(0.097)^{* * *}$

$-0.649(0.071)^{* * *}$

Yes
(2)

Estimation period (1988:1-2002:4)

(1) NPV of wages: equivalent monthly wage

(2) NPV of wages: NPV/match duration

Lagged unemployment

rate (levels)
$-0.625(0.093)^{* * *}$

$-0.610(0.086)^{* * *}$

Yes

Each coefficient is a separate second stage regression of the estimated year-quarter coefficients on the yearly-lagged quarterly unemployment rate. All second stage regressions include a constant term, a linear time trend and quarter indicators. The first column contains 96 quarterly observations (1988:1-2011:4) and the second column contains 60 quarterly observations (1988:1-2002:4). The number of observations in the first stage is $1,677,664$ for rows (1) and (2). ${ }^{* * *},{ }^{* *}$, and ${ }^{*}$ indicate significance at the 1,5 , and 10 percent levels

compositional effects along the cycle by including worker fixed-effects, yet, now the estimation drops those workers who do not switch jobs throughout 1988-2011. ${ }^{26}$

Table 5 presents the results of the estimation. The NPV of equivalent wages in new matches is as cyclical as wages of newly-hired workers and somewhat higher than wages of job-movers. In general, a decline of one percentage point in the unemployment rate is associated with an increase in the NPV of equivalent wages in a new match of $0.65 \%-0.77 \%$. When I restrict the sample in column (2) to matches created before 2002 to address right censoring in job durations, I obtain a slightly smaller semi-elasticity. ${ }^{27}$ This finding resembles that of Haefke et al. (2013) who obtain using CPS data an essentially identical response for both wages of newly-hireds and NPV of wages to changes in productivity. In contrast, Kudlyak (2013) finds evidence of greater cyclicality of NPV of wages relative to wages of newly-hired workers using NLSY data. The main difference between my findings and the estimates in these studies is that I exploit actual match-specific data on wages and job durations and, hence, there is no need to simulate the profile of matches.

\section{Conclusions}

This paper provides estimates of real wage cyclicality in Spain during the period 1988-2011. The baseline estimate shows wages are weakly procyclical with a small increment of $0.4 \%$ in response to a decline of one percentage point in the unemployment rate. Earlier studies that estimate wage cyclicality using worker-level data find much stronger wage responses for countries with more flexible labour markets, mainly the United States and the United Kingdom. Therefore, this finding indicates

\footnotetext{
26 Of the 513,058 workers in the initial sample, 71,382 (13.9\%) do not switch jobs during the estimation period.

27 The 90th percentile in the distribution of job durations of new matches between 1988-2002 (and further observed until 2011) is 99 months. Thus, I get rid of almost all right censoring in durations when applying this restriction.
} 
that in countries with institutions that deter firms to adjust wages to business cycle conditions-Spain being one good example-real wage cyclicality is weaker than previously thought.

The result I find on different wage cyclicality estimates for workers under permanent and temporary contracts mirrors the duality in the Spanish labour market. The estimated real wage cyclicality for workers under a temporary contract is twice as large as the cyclicality level for workers under a permanent contract. Although I do not examine differences in extensive margin cyclical responses between workers in permanent and temporary contracts, it has been documented that the latter also face higher turnover rates (Dolado et al. 2002). Therefore, policies in favour of reducing disparities between workers under both types of contract should generate a more balanced response of wages to business cycles conditions for both types of workers.

Finally, I provide evidence that wage cyclicality decreases consistently with the level of job tenure. The finding that wages of newly-hired workers are more volatile than wages of job stayers does not support wage rigidity as a solution to the unemployment-volatility puzzle. In the Mortensen-Pissarides search and matching model the key piece of information to determine the number of jobs created is the cyclicality of the net present value of wages in new matches. Using actual matchspecific data on wages and job durations, I obtain a cyclicality estimate for this net present value of wages in new matches of the same order as the one I find for wages of newly-hired workers.

Open Access This article is distributed under the terms of the Creative Commons Attribution License which permits any use, distribution, and reproduction in any medium, provided the original author(s) and the source are credited.

\section{Appendix: Fit of simulated earnings}

To examine the fit of the simulation, I compare the distribution of simulated daily wages from MCVL to the distribution of actual uncensored daily earnings from income tax returns for the same individual and month in those years where both are available (2004-2011). If the fit is reasonably close for 2004-2011, this will provide some

Table 6 Selected percentiles for actual and simulated wages

\begin{tabular}{llllll}
\hline & \multicolumn{2}{l}{ All workers } & & \multicolumn{2}{l}{ Skilled workers } \\
\cline { 2 - 3 } \cline { 5 - 6 } & Total salaries & Simulated wages & & Total salaries & Simulated wages \\
\hline Percentile 10 & 53.2 & 52.8 & & 45.2 & 46.2 \\
Percentile 25 & 62.5 & 62.2 & 60.2 & 62.0 \\
Percentile 50 & 79.0 & 78.8 & & 85.0 & 88.1 \\
Percentile 75 & 114.0 & 116.1 & & 123.4 & 129.7 \\
Percentile 90 & 169.9 & 175.9 & & 172.8 & 168.6 \\
\hline
\end{tabular}

Monthly salaries and wages expressed as a percentage of the average in each category. Skilled individuals work in the top three out of ten social security occupations 
Table 7 Order of autocorrelations for actual and simulated wages

\begin{tabular}{lll}
\hline Order & Total salaries & Simulated wages \\
\hline 1 & 0.939 & 0.935 \\
2 & 0.908 & 0.907 \\
3 & 0.882 & 0.881 \\
4 & 0.861 & 0.859 \\
5 & 0.843 & 0.842 \\
6 & 0.828 & 0.825 \\
7 & 0.809 & 0.808 \\
\hline
\end{tabular}

validation that the distribution of simulated wages can accurately approximate the distribution of earnings or total salaries for the years 1988-2003.

The correlation between simulated daily wages and actual daily total salaries for capped observations is high at 0.77 . Simulated wages can reproduce to some extent the overall shape of the salaries distribution. This can be seen in Table 6, which presents selected percentiles of the distributions of total salaries and simulated wages for all workers and for skilled workers (those in the top three occupation categories in social security). Overall, the distributions are quite similar, though simulated wages exceed total salaries in the 90th percentile. More important, for skilled workers, who are top-coded beyond the 52nd percentile, simulated wages can approximate salaries in capped percentiles.

Table 7 displays estimated order of autocorrelations for total salaries and simulated wages. In this case, the level of persistence observed in both total salaries and wages in MCVL is remarkably similar.

\section{References}

Babecký J, Du Caju P, Kosma T, Martina L, Julián M, Tairi R (2010) Downward nominal and real wage rigidity: aurvey evidence from European firms. Scand J Econ 112(4):884-910

Bentolila S, Izquierdo M, Jimeno JF (2010) Negociación colectiva: La gran reforma pendiente. Papeles de Economía Espa nola 124:176-192

Bils MJ (1985) Real wages over the business cycle: evidence from panel data. J Polit Econ 93(4):666-689

Bjorklund A (1993) A comparison between actual distributions of annual and lifetime income: Sweden 1951-89. Rev Income Wealth 39(4):377-386

Card D, Heining J, Kline P (2013) Workplace heterogeneity and the rise of West German wage inequality. Q J Econ 128(3):967-1015

Carneiro A, Guimaraes P, Portugal P (2012) Real wages and the business cycle: accounting for worker and firm heterogeneity. Am Econ J Macroecon 4(2):133-152

Cuadrado P, Pablo Hernández de Cos, Mario Izquierdo (2011) El ajuste de los salarios frente a las perturbaciones de Espa na. Economic Bulletin 2, Banco de Espa na.

Devereux PJ (2001) The cyclicality of real wages within employer-employee matches. Ind Labor Relat Rev 54(4):835-850

Devereux PJ, Hart RA (2006) Real wage cyclicality of job stayers, within-company job movers, and betweencompany job movers. Ind Labor Relat Rev 60(1):105-119

Dickens WT, Lorenz G, Groshen EL, Holden S, Messina J, Schweitzer ME, Turunen J, Ward ME (2007) How wages change: micro evidence from the International Wage Flexibility project. J Econ Perspect 21(2):195-214

Dolado JJ, García-Serrano C, Jimeno JF (2002) Drawing lessons from the boom of temporary jobs in Spain. Econ J 112(721):270-295 
Druant M, Fabiani S, Kezdi G, Lamo A, Martins F, Sabbatini R (2012) Firms' price and wage adjustment in Europe: survey evidence on nominal stickiness. Labour Econ 19(5):772-782

Estrada Á MI (2005) La producción y el mercado de trabajo. In: Servicio de Estudios del Banco de Espa na (ed.) El análisis de la economía espa nola. Alianza Editorial, Madrid, pp 347-377

García-P José I (2008) La muestra continua de vidas laborales: Una guía de uso para el análisis de transiciones. Revista de Economía Aplicada 26(1):5-28

Haefke C, Sonntag M, van Rens T (2013) Wage rigidity and job creation. J Monet Econ 60(8):887-899

Haider S, Solon G (2006) Life-cycle variation in the association between current and lifetime earnings. Am Econ Rev 96(4):1308-1320

Hall RE (2005) Employment fluctuations with equilibrium wage stickiness. Am Econ Rev 95(1):50-65

Holden S, Fredrik W (2008) Downward nominal wage rigidity in the oecd. BE J Macroecon 8(1):1-48

Izquierdo M, Pilar C (2009) La encuesta sobre formación de salarios de las empresas espa nolas: Nueva evidencia sobre la relación entre precios y salarios, y la respuesta de las empresas a perturbaciones económicas. Economic Bulletin 3, Banco de Espa na

Kudlyak M (2013) The cyclicality of the user cost of labor. Working Paper 09-12R, Federal Reserve Bank of Richmond

Mortensen DT, Pissarides CA (1994) Job creation and job destruction in the theory of unemployment. Rev Econ Stud 61(3):397-415

Moulton BR (1986) Random group effects and the precision of regression estimates. J Econom 32(3):385397

Pissarides CA (2000) Equilibrium unemployment theory, 2nd edition. MIT Press, Cambridge

Pissarides CA (2009) The unemployment volatility puzzle: is wage stickiness the answer? Econometrica 77(5):1339-1369

Shimer R (2005) The cyclical behavior of equilibrium unemployment and vacancies. Am Econ Rev 95(1):25-49

Shin D (1994) Cyclicality of real wages among young men. Econ Lett 46(2):137-142

Solon G, Barsky R, Parker JA (1994) Measuring the cyclicality of real wages: how important is composition bias? Q J Econ 109(1):1-25 